\title{
Hemoglobin F Concentration as a Function of Age in Kuwaiti Sickle Cell Disease Patients
}

\author{
Adekunle Adekile ${ }^{a} \quad$ Mohammed Al-Kandaric Mohammad Haider ${ }^{\mathrm{a}}$ \\ Marouf Rajaa $^{b}$ Mark D'Souza $^{a}$ Jalaja Sukumaran ${ }^{a}$ \\ Departments of a Pediatrics and ${ }^{b}$ Pathology, Faculty of Medicine, Kuwait University, and \\ 'Department of Pathology, Mubarak Hospital, Kuwait
}

\section{Key Words}

Hemoglobin F, Kuwait · Sickle cell disease •

Hemoglobin F, age

\begin{abstract}
Objective: This study aimed to document the transition of hemoglobin $(\mathrm{Hb})$ F levels from early childhood to adulthood in Kuwaiti sickle cell disease patients, investigating its relationship to sex, $\mathrm{Hb}$ genotype and coexistence of $\alpha$-thalassemia trait. Subjects and Methods: The following parameters were extracted from the patients' records: age, sex, $\mathrm{Hb}$, mean corpuscular volume, mean corpuscular $\mathrm{Hb}$, red blood cell count, $\mathrm{Hb}$ F, $\mathrm{Hb}$ S, $\mathrm{Hb} \mathrm{A}_{2}$ and $\alpha$-globin genotype. Hb quantitation was performed with cation exchange HPLC, while $\alpha$ globin genotype was determined by PCR. Results: Records were available for 149 patients, made up of 94 SS and 55 $\mathrm{S} \beta^{0}$ thal; 83 males and 66 females, aged 3 months to 60 years (mean $10.5 \pm 1.8$ ). The mean $\mathrm{Hb}$ F level in the whole population was $21.5 \pm 8.1 \%$ and was not significantly different between males and females, and SS or $\mathrm{S}^{0}$ thal. When the age groups were analyzed, the $\mathrm{Hb} \mathrm{F}$ level was highest (28.9 \pm $10.9 \%$ ) in those below 5 years. Indeed, patients $\leq 2$ years had a mean level of $31.9 \pm 13.0 \%$. There was no significant difference in the $\mathrm{Hb}$ F levels in SS patients with or without coexistent $\alpha$-thal trait. Conclusions: Kuwaiti sickle cell disease
\end{abstract}

patients below 5 years of age have close to $30 \% \mathrm{Hb} F$ and this is probably a major reason why they usually do not present before this age, unlike patients elsewhere who present within the first year of life.

Copyright $\odot 2007$ S. Karger AG, Basel

\section{Introduction}

Sustained postnatal expression of fetal hemoglobin $(\mathrm{Hb} \mathrm{F})$ is perhaps the most widely recognized and the most thoroughly studied genetic modulator of sickle cell disease (SCD) severity [1]. All infants, including those with SCD, are born with a high level of Hb F (85-95\%) and its decrease after birth is considerably faster in normal infants than in those with SCD. Furthermore, in $\mathrm{Hb}$ SS patients $\geq 1$ year old, the levels of $\mathrm{Hb} F$ vary considerably but appear to be constant in each patient after the age of 5-7 years [1-4]. Several factors affect its variability, the most important of which is the chromosomal $\beta^{\mathrm{S}}$-globin gene haplotype. Patients with the Saudi Arabia/India (SAI) or the Senegal haplotype carry the $-158 \mathrm{C} \rightarrow \mathrm{T} \mathrm{mu}-$ tation in the ${ }^{\mathrm{G}} \gamma$-promoter, which is associated with a sustained elevation of $\mathrm{Hb} \mathrm{F}[4,5]$. Coexistent $\alpha$-thal trait has an inverse relationship with $\mathrm{Hb}$ F levels in SS patients because of preferential survival of non-F cells [6]. However,

\section{KARGER}

Fax +4161306 1234

E-Mail karger@karger.ch

www.karger.com
(C) 2007 S. Karger AG, Basel

$1011-7571 / 07 / 0164-0286 \$ 23.50 / 0$

Accessible online at:

www.karger.com/mpp
Prof. Adekunle D. Adekile

Department of Pediatrics, Faculty of Medicine, Kuwait University PO Box 24923

13110 Safat (Kuwait)

Tel. +965 531 9486, Fax +965 533 08940, E-Mail adekile@hsc.edu.kw 
Table 1. Hematological data on patients according to sex

\begin{tabular}{lllllll}
\hline Sex & Patients & $\begin{array}{l}\mathrm{Hb} \\
\mathrm{g} / \mathrm{dl}\end{array}$ & $\begin{array}{l}\mathrm{MCV} \\
\mathrm{fl}\end{array}$ & $\begin{array}{l}\mathrm{MCH} \\
\mathrm{pg}\end{array}$ & $\begin{array}{l}\mathrm{Hb} \mathrm{F} \\
\%\end{array}$ & $\begin{array}{l}\mathrm{Hb} \mathrm{A}_{2} \\
\%\end{array}$ \\
\hline Male & 83 & $10.9 \pm 1.9$ & $79.4 \pm 11.8$ & $26.7 \pm 4.6$ & $22.2 \pm 9.0$ & $4.2 \pm 2.1$ \\
Female & 66 & $10.1 \pm 1.5$ & $78.3 \pm 9.7$ & $26.1 \pm 3.8$ & $20.6 \pm 6.8$ & $3.9 \pm 1.7$ \\
All & 149 & $10.5 \pm 1.8$ & $78.9 \pm 10.8$ & $26.4 \pm 4.2$ & $21.5 \pm 8.1$ & $4.1 \pm 1.9$ \\
\hline
\end{tabular}

No statistically significant differences in any of the mean values between males and females. other studies did not indicate this relationship [7]. Female gender may also play a role in maintaining a high $\mathrm{Hb} \mathrm{F}$ level because of a gene linked to the $\mathrm{X}$ chromosome located at Xp22.2 that influences F cell production $[5,8]$.

SCD is relatively mild among Kuwaiti patients. Stroke, early splenic dysfunction, chronic leg ulcers, acute chest syndrome and priapism are all relatively uncommon [913]. Unlike patients in Africa and the USA, who present with clinical features within the first year of life, Kuwaiti patients do not present until 4-5 years of age. It is believed that this is due to the high $\mathrm{Hb}$ F level, but since there are no newborn screening programs to identify infants at birth and follow $\mathrm{Hb} \mathrm{F}$ levels, documentation of changes in $\mathrm{Hb} \mathrm{F}$ levels prior to diagnosis is lacking in early life in these patients. There have been a few SCD patients born to parents of patients being followed in the Pediatric Hematology Clinic in the Mubarak and Amiri Hospitals in Kuwait. Some of these have been followed from infancy and their $\mathrm{Hb} \mathrm{F}$ levels recorded serially. These are included in the present report. This study sought to investigate the following concerning $\mathrm{Hb} \mathrm{F}$ levels in our patients: agerelated differences, influence of gender, any differences between SS and $S \beta^{0}$-thal patients and influence of coexistent $\alpha$-thal trait.

\section{Subjects and Methods}

The SCD patients in this study were followed in the Hematology Clinics (both pediatric and adult) of the Mubarak and Amiri Hospitals. All patients seen in the clinic have blood drawn at their first visit for hematological and DNA studies in the Hemoglobin Research Laboratory, Department of Pediatrics, Kuwait University. Automated complete blood count is obtained by electronic counter (Coulter S), while Hb quantitation is obtained by cation exchange high performance liquid chromatography [14].

DNA is extracted by the method of Poncz et al. [15]; $\beta^{S}$-globin haplotypes were determined using allele-specific oligonucleotide hybridization looking for haplotype-specific mutations in the ${ }^{\mathrm{G}} \gamma$ and ${ }^{\mathrm{A}} \gamma$-globin gene promoter regions [16]. Only patients carrying

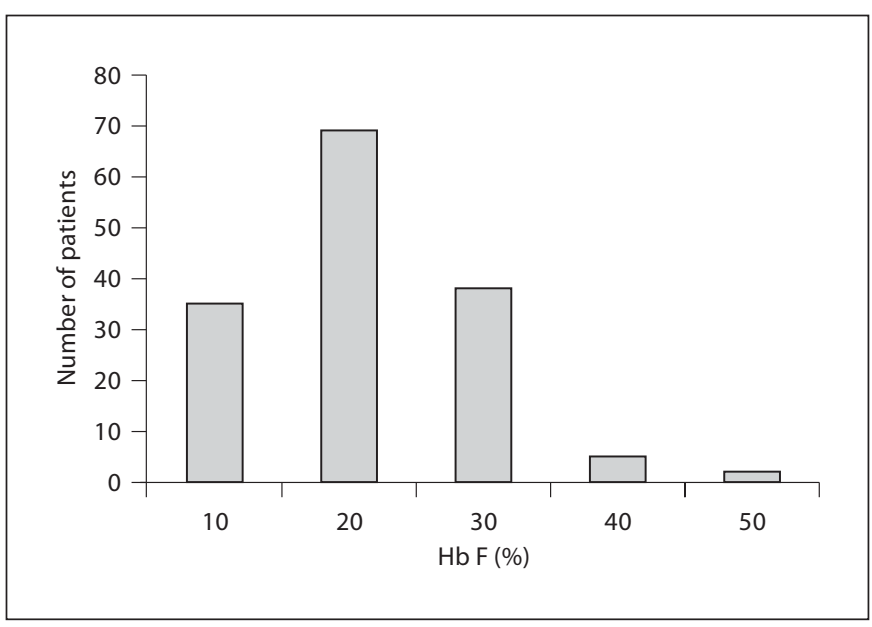

Fig. 1. Distribution of $\mathrm{Hb} \mathrm{F}$ in all patients.

the SAI $\beta^{\text {S }}$-haplotype either as homozygotes or compound heterozygotes were included in the study. Three patients (2 Benin haplotype homozygotes and 1 Bantu homozygote) were excluded. All the patients were screened for the $\alpha$-thal-2, $-3.7 \mathrm{~kb}$ deletion, which is the commonest cause of $\alpha$-thalassemia in this population, using a PCR-based technique [17]. Hb SS patients who did not have the $\alpha$-thal-2 deletion, but still had significant microcytosis and/or hypochromia, were further screened for the $\alpha 2$ polyadenylation signal mutation (AATAA $\underline{A} \rightarrow$ AATAA $\underline{\text { ) }}$, which is the second most common $\alpha$-thal determinant in our patients, using hybridization techniques with ECL-labeled specific synthetic oligonucleotides as previously reported $[9,10]$.

The following data were extracted from the patients' records: name, age, sex, $\beta$-globin genotype, $\mathrm{Hb}$, mean corpuscular volume $(\mathrm{MCV})$, mean corpuscular hemoglobin $(\mathrm{MCH})$, red blood cell count, $\mathrm{Hb} \mathrm{F}, \mathrm{Hb} \mathrm{S}$ and $\mathrm{Hb} \mathrm{A}_{2}$. The $\alpha$-globin genotype for the SS patients was documented.

Data are presented as means \pm SD and Statistical Package for the Social Sciences software version 13.0 was used for statistical analysis. Differences between 2 mean values were evaluated by Student's t test and when more than 2, analysis of variance (ANOVA) was done. 
Fig. 2. Distribution of $\mathrm{Hb} \mathrm{F}$ by age.

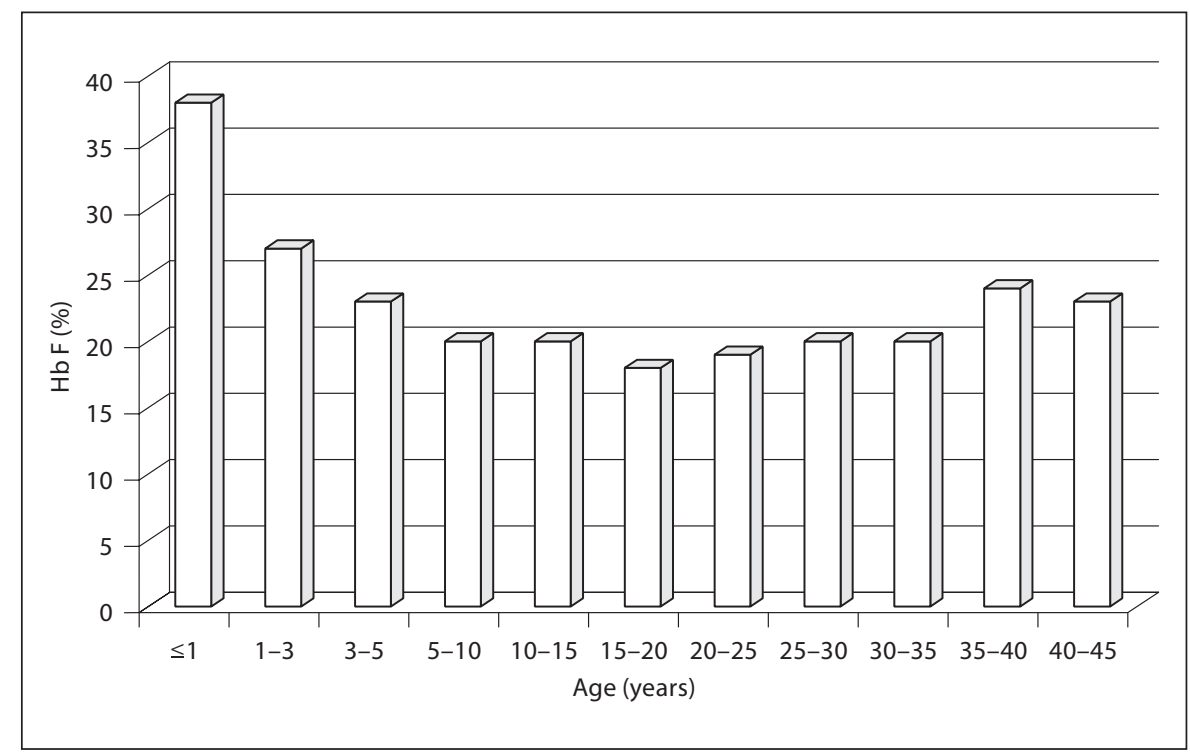

Table 2. Hematological data in SS and $\mathrm{S} \beta^{0}$ thal patients

\begin{tabular}{lllllll}
\hline Genotype & Patients & $\begin{array}{l}\mathrm{Hb} \\
\mathrm{g} / \mathrm{dl}\end{array}$ & $\begin{array}{l}\mathrm{MCV} \\
\mathrm{fl}\end{array}$ & $\begin{array}{l}\mathrm{MCH} \\
\mathrm{pg}\end{array}$ & $\begin{array}{l}\mathrm{Hb} \mathrm{F} \\
\%\end{array}$ & $\begin{array}{l}\mathrm{Hb} \mathrm{A}_{2} \\
\%\end{array}$ \\
\hline $\mathrm{SS}$ & 94 & $10.6 \pm 1.7$ & $82.8 \pm 10.8$ & $28.0 \pm 4.3$ & $21.3 \pm 6.4$ & $3.7 \pm 2.0$ \\
$\mathrm{~S} \beta^{0}$ thal & 55 & $10.4 \pm 1.9$ & $73.2 \pm 8.0$ & $24.1 \pm 3.1$ & $22.5 \pm 10.3$ & $5.8 \pm 5.1$ \\
\hline
\end{tabular}

Only the values of MCV and $\mathrm{MCH}$ were significantly different between the 2 groups $(\mathrm{p}<0.05)$.

\section{Results}

Records from a total of 149 SCD patients were reviewed. They were aged from 3 months to 60 years with a mean of $10.5 \pm 1.8$ years, made up of 83 males and 66 females. All were SAI homozygotes, except for 4 patients, who were compound heterozygotes for the SAI and Benin haplotypes and did not show any significant differences in any parameter examined when compared to the SAI homozygotes. Table 1 shows the mean hematological parameters for the whole population and males and females. The mean values of all the parameters including $\mathrm{Hb} F$ were not significantly different in the 2 groups. Figure 1 also shows the distribution of $\mathrm{Hb} \mathrm{F}$ in the whole population; most of the patients had $\mathrm{Hb} F$ between 20 and $30 \%$. Figure 2 shows the distribution of $\mathrm{Hb} \mathrm{F}$ by age; there is a gradual decrease from $<1$ to 5 years of age, after which it tends to level out.
Table 2 shows the hematological values for the SS and $S \beta^{0}$ thal groups. The mean values were similar in both groups, except for $\mathrm{MCV}$ and $\mathrm{MCH}$, which were significantly lower in the latter $(\mathrm{p}<0.05)$.

Table 3 shows the hematological parameters divided according to 4 age groups. ANOVA testing showed that the means of the individual variables were similar in all groups, except for $\mathrm{Hb} \mathrm{F}$, which was significantly different $(\mathrm{F}=7.8, \mathrm{p}<0.0001)$.

Table 4 shows the hematological values among the $\mathrm{Hb}$ SS patients divided according to the $\alpha$-globin genotypes. ANOVA testing showed no significant differences in the distribution, except for MCV $(\mathrm{F}=2.7, \mathrm{p}<0.05)$. When the patients with $2 \alpha$-globin genes were combined with those with 3 and then compared to those with 4 genes, the mean values showed significant differences $(\mathrm{p}<0.05)$ in $\mathrm{MCV}, \mathrm{MCH}$ and red blood cell count. 
Table 3. Hematological data in different age groups

\begin{tabular}{lllllll}
\hline Age & Patients & $\begin{array}{l}\mathrm{Hb} \\
\mathrm{g} / \mathrm{dl}\end{array}$ & $\begin{array}{l}\mathrm{MCV} \\
\mathrm{fl}\end{array}$ & $\begin{array}{l}\mathrm{MCH} \\
\mathrm{pg}\end{array}$ & $\begin{array}{l}\mathrm{Hb} \mathrm{F} \\
\%\end{array}$ & $\begin{array}{l}\mathrm{Hb} \mathrm{A}_{2} \\
\%\end{array}$ \\
\hline$<5$ years & 27 & $10.6 \pm 2.1$ & $75.9 \pm 11.1$ & $25.1 \pm 3.6$ & $28.9 \pm 10.9$ & $3.7 \pm 1.8$ \\
$\geq 5$-10 years & 20 & $10.1 \pm 1.3$ & $73.3 \pm 9.0$ & $24.0 \pm 4.0$ & $20.1 \pm 7.4$ & $4.2 \pm 1.4$ \\
$\geq 10-15$ years & 31 & $10.1 \pm 1.1$ & $79.4 \pm 10.5$ & $26.9 \pm 4.0$ & $18.9 \pm 6.8$ & $4.5 \pm 2.1$ \\
$>15$ years & 71 & $10.8 \pm 2.0$ & $81.1 \pm 10.9$ & $26.4 \pm 4.2$ & $21.5 \pm 8.1$ & $4.1 \pm 1.9$ \\
\hline
\end{tabular}

$\mathrm{Hb}$ F: ANOVA showed $\mathrm{p}<0.0001$; no significant differences in other parameters.

\begin{tabular}{lllllll}
\hline $\begin{array}{l}\alpha \text {-Globin } \\
\text { genes }\end{array}$ & Patients & $\begin{array}{l}\mathrm{Hb} \\
\mathrm{g} / \mathrm{dl}\end{array}$ & $\begin{array}{l}\mathrm{MCV} \\
\mathrm{fl}\end{array}$ & $\begin{array}{l}\mathrm{MCH} \\
\mathrm{pg}\end{array}$ & $\begin{array}{l}\mathrm{Hb} \mathrm{F} \\
\%\end{array}$ & $\begin{array}{l}\mathrm{Hb} \mathrm{A}_{2} \\
\%\end{array}$ \\
\hline 2 & 6 & $12.0 \pm 1.8$ & $75.4 \pm 3.9$ & $24.9 \pm 1.7$ & $17.9 \pm 4.4$ & $3.5 \pm 0.9$ \\
3 & 27 & $10.7 \pm 1.6$ & $79.0 \pm 7.3$ & $26.6 \pm 3.2$ & $21.1 \pm 6.5$ & $3.8 \pm 1.9$ \\
4 & 46 & $10.7 \pm 1.7$ & $87.3 \pm 11.6$ & $29.1 \pm 4.7$ & $21.5 \pm 6.5$ & $3.7 \pm 2.1$ \\
\hline
\end{tabular}

$\mathrm{Hb}$ F: ANOVA showed $\mathrm{p}<0.05$; other parameters showed no significant differences.
Table 4. Hematological data in SS patients according to $\alpha$-globin gene number

\section{Discussion}

There has been considerable interest in $\mathrm{Hb} F$ in SCD since when it was first noticed that the disease is not expressed in newborns and young infants. Later studies also demonstrated a protective effect of $\mathrm{Hb} \mathrm{F}$ on the symptomatology and organ dysfunction associated with the disease. It was estimated that an $\mathrm{Hb} \mathrm{F}$ level of $20 \%$ protects against end-organ damage, while patients with $\mathrm{Hb} \mathrm{F}$ of $\geq 30 \%$ are symptom free [1].

Detailed analysis of Hb F levels in SCD patients with the SAI haplotype had not been previously carried out. Of particular interest are $\mathrm{Hb} F$ levels in those aged $<5$ years, who rarely present with features of the disease. The results in the present study confirm previous reports of elevated Hb F levels in SCD patients with the SAI haplotype and, as hypothesized, the levels were highest in those $<5$ years of age. In the latter age group, the mean level ( $>30 \%$ ) was highest in those $\leq 2$ years. The association between SAI haplotype and elevated $\mathrm{Hb} F$ level (irrespective of $\alpha$-globin genotype) is the likely reason why our patients do not usually present with symptoms of SCD before the age of 5 years. This has several implications for the eventual complications of the disease. Brain infarcts develop quite early in life in these patients because the brain is particularly vulnerable to ischemic injury at this time. Stroke is probably the most devastating complication and it occurs in about 7-10\% of American children with the disease [18]. Silent brain infarcts are even more common, occurring in 17-20\% [19]. By contrast, among our patients in Kuwait, stroke is exceedingly rare and silent infarcts are seen in only about $3 \%$ below the age of 16 years [12]. It appears that our patients do not develop the early vasculopathy that leads to infarcts because at the critical time, their high $\mathrm{Hb} \mathrm{F}$ exceeds the threshold at which the process is initiated [20]. It should be noted that the cooperative sickle cell study in the USA found no association between the $\mathrm{Hb}$ F level and stroke in SCD patients, but the study did not take into consideration the level in early childhood, i.e. $<5$ years $[18,21]$. Moreover, $\mathrm{Hb} \mathrm{F}$ levels at this age are much higher in SAI homozygotes than in most American patients.

The other significant complication, which is responsible for most deaths in children with SCD, is bacterial infection. Among American patients, functional asplenia is virtually universal by the age of 2 years [22]. It is caused by recurrent infarction within the splenic sinusoids. This progresses to fibrosis and autosplenectomy by the age of 8-10 years. By contrast, in a study of 6- to 16 -year-old Kuwaiti patients, about $75 \%$ retained full or partial spleen function as shown by radio-colloid uptake. This again is attributable to the high level of $\mathrm{Hb} \mathrm{F}$ in addition to coexistent $\alpha$-thal trait, which has been shown to promote sustained splenic function $[13,23]$.

Unlike reports in the literature, we were unable to demonstrate a higher $\mathrm{Hb}$ F level in females in comparison to male SCD patients. It would appear that the X-linked factor, which influences $\mathrm{Hb} F$ production [8], is not im- 
portant in patients with SAI haplotype in whom the -158 $\mathrm{C} \rightarrow \mathrm{T}$ mutation in the ${ }^{\mathrm{G}} \gamma$-promoter confers maximal $\mathrm{F}$ expression. However, our SS patients with $\alpha$-thal trait (2-gene deletion) had the lowest $\mathrm{Hb} F$ levels as have been reported in the literature [6], although the difference was not statistically significant.

The present study is limited because it is not a prospective study, correlating clinical severity with the laboratory parameters examined. Moreover, SCD is increasingly being seen as a multigene disease and there are polymorphisms in diverse loci that have an impact on the disease. Enhancer and silencer elements in the ${ }^{\mathrm{G}} \gamma$ - and ${ }^{\mathrm{A}} \gamma$-globin gene promoters and in the locus control region all play roles in interacting with the $\mathrm{X} m n \mathrm{I}$ site in the ${ }^{\mathrm{G}} \gamma$-promoter in controlling $\gamma$-globin expression and therefore $\mathrm{Hb} F \mathrm{lev}$ els in SCD patients [24]. Chronic activation of the endo- thelium in SCD sets off cascades of inflammatory processes leading to vasculopathy. Involved in this process are neutrophils, platelets, adhesion molecules, cytokines and other mediators. All these are under genetic control and polymorphisms in the relevant genes are being studied for their roles in the SCD phenotype [25-27]. These need to be extended to patients of different chromosomal haplotypes and different ethnic backgrounds.

\section{Conclusion}

Unlike patients elsewhere who present within the first year of life, Kuwaiti SCD patients $<5$ years of age have close to $30 \% \mathrm{Hb} F$ and this is probably a major reason why they are usually not symptomatic at this age.

\section{References}

$\checkmark 1$ Powars DR, Weiss JN, Chan LS, Schroeder WA: Is there a threshold level of fetal hemoglobin that ameliorates morbidity in sickle cell anemia? Blood 1984;63;921-926.

$>2$ Powars DR: Sickle cell anemia: beta S-genecluster haplotypes as prognostic indicators of vital organ failure. Semin Hematol 1991;28: 180.

-3 Wrightstone RN, Huisman THJ: On the levels of hemoglobins $\mathrm{F}$ and $\mathrm{A}_{2}$ in sickle cell anemia and some related disorders. Am J Clin Pathol 1974;61:375-381.

$\checkmark 4$ Adekile AD, Huisman THJ: Hb F in sickle cell anaemia. Experientia 1993;49:16-27.

5 Nagel RL and Ranney HM: Genetic epidemiology of the $\beta$-globin gene. Semin Hematol 1990;27:332-349.

-6 Dover GJ, Chang VT, Boyer SH, Serjeant GR, Antonarakis SE, Higgs DR: The cellular basis for different fetal hemoglobin levels among sickle cell individuals with two, three and four $\alpha$-globin genes. Blood 1987;69:341-344.

$>7$ Steinberg MH, Rosenstock W, Coleman MB, Adams JG, Platica O, Cedeno M, Rieder RF, Wilson JT, Milner P, West S: Effects of thalassemia and microcytosis on the hematologic and vasoocclusive severity of sickle cell anemia. Blood 1984;63:1353-1360.

$>8$ Morris J, Dunn D, Beckford M, Grandison Y, Mason K, Higgs DR, De Ceulear K, Serjeant BE, Serjeant GR: The haematology of sickle cell disease after the age of forty years. Br J Haematol 1991;77:382-385.

$\checkmark 9$ Adekile AD, Gu L-H, Baysal E, Haider MZ, Al-Fuzae L, Aboobacker KC, Al-Rashied A, Huisman THJ: Molecular characterization of $\alpha$-thalassaemia determinants, $\beta$-thalassaemia alleles and $\beta S$ haplotypes among Kuwaiti Arabs. Acta Haematol 1994;92:176-181.

10 Adekile AD, Haider MZ: Morbidity, $\beta^{\mathrm{S}}$ haplotype and $\alpha$-globin gene patterns among sickle cell anemia patients in Kuwait. Acta Haematol 1996;96:150-154.

11 Adekile AD, Gupta R, Yacoub F, Sinan T, AlBloushi M, Haider MZ: Avascular necrosis of the hip in Kuwaiti children with sickle cell disease: MRI images and association with $\alpha$ thalassemia trait. Acta Haematol 2001;105: 27-31.

12 Adekile AD, Yacoub F, Gupta R, Sinan T, AlBloushi M, Haider MZ, Habib Y, Moosa A: Silent brain infarcts are rare in Kuwaiti children with sickle cell disease and elevated $\mathrm{Hb}$ F. Am J Hematol 2002;70:228-231.

$\checkmark 13$ Adekile AD, Owunwanne A, Al-Za'abi K, Haider MZ, Tuli M, Al-Mohannadi S: Temporal sequence of splenic dysfunction in sickle cell disease. Am J Hematol 2002;69:23-27.

14 Bissé E, Wieland H: High-performance chromatographic separation of human haemoglobins: simultaneous quantitation of foetal and glycated haemoglobins. J Chromatogr 1988; 434:95-110.

15 Poncz M, Solowiejczyk D, Harpel B, Mory Y, Schwartz E, Surrey S: Construction of human gene libraries from small amounts of peripheral blood: analysis of $\beta$-like globin genes Hemoglobin 1982;6:27-36.

16 Lanclos KD, Oner C, Dimovski AJ, Gu Y-C, Huisman THJ: Sequence variations in the $5^{\prime}$ flanking and IVS-II regions of the $\mathrm{G} \gamma$ - and A $\gamma$-globin genes of $\beta^{S}$ chromosomes with five different haplotypes. Blood 1991;77:24882496.

7 Baysal E, Huisman THJ: Detection of common deletional $\alpha$-thalassemia-2 determinants by PCR. Am J Hematol 1994;46:208213.

18 Ohene-Frempong K.: Stroke in sickle cell disease: demographic, clinical, and therapeutic considerations. Semin Hematol 1991;28:213219.
19 Moser FG, Miller ST, Bello JA, Pegelow CH, Zimmerman RA, Wang WC, Ohene-Frempong K, Schwartz A, Vichinsky EP, Gallagher D, Kinney TR: The spectrum of brain MR abnormalities in sickle cell disease: a report from the cooperative study of sickle cell disease. AJNR 1996;17:965-972.

20 Marouf R, Gupta R, Haider MZ, Adekile AD: Silent brain infarcts in adult Kuwaiti sickle cell disease patients. Am J Hematol 2003;73: 240-243.

21 Ohene-Frempong K, Weiner SJ, Sleeper LA, Miller ST, Embury S, Moohr JW, Wethers DL, Pegelow CH, Gill FM: Cerebrovascular accidents in sickle cell disease: rates and risk factors. Blood 1998;91:288-294.

22 Pearson HA, Spencer RP, Cornelius EA: Functional asplenia in sickle cell anemia. N Engl J Med 1969;282:923-926.

$>23$ Adekile AD, Tuli M, Haider MZ, Al-Zaabi K, Al-Mohannadi S, Owunwanne O: Influence of $\alpha$-thal trait on spleen function in sickle cell anemia patients with high $\mathrm{HbF}$. Am J Hematol 1996;53:1-5.

24 Stamatoyannopoulus G: Control of globin gene expression during development and erythroid differentiation. Exp Hematol 2005;33: 259-271.

25 Styles LA, Hoppe C, Klitz W, Vichinsky E, Lubin B, Trachtenberg E: Evidence for HLA related susceptibility for stroke in children with sickle cell disease. Blood 2000;95:3562-3567.

26 Chui DHK, Dover GJ: Sickle cell disease: no longer a single gene disorder. Curr Opin Pediatr 2001;13:22-27.

27 Kutlar A: Sickle cell disease: a multigenic perspective of a single gene disorder. Med Princ Pract 2005;14:15-19. 